\title{
OF NOTABLE PIANO CONCERTOS, NEGLECTED AND OTHERWISE
}

\author{
By H. H. BELLAMANN
}

$\mathrm{C}$ ONCERT-GIVERS and concert-goers have conspired to make certain piano concertos distressingly well known to us. The innumerable repetitions of these concertos, judged by the legitimate demands of musical progress, seems unjustifiable; but the experience of those intrepid enough to venture the unfamiliar, exhibit some results of sufficient weight to give us pause in the very act of censuring the less courageous.

A most excellent pianist-a pianist of eclectic tastes and immense repertoire, played in London recently a concerto by Tcherepnin. An habitual concert-goer said, "Oh, I can't go and sit through an unfamiliar work!"

There was but slight critical remark in the press-neither the concerto nor the playing received anything like the fullness of comment which followed later performances by the same pianist of more familiar works. It is, of course, not conceivable that the deprivation of certain familiar critical hand-holds could deter critics and public from an expression of either approval or disapproval. It must be attributed to a state of mind that is quickened from apathy only by the anticipation of familiar applausemaking moments which render comparative criticism easy.

We are frequently pleased by the utterances of platitudes because we believe they give expression to something which we believe we have thought for ourselves. The confirmation of our views is flattering though it may be of things the world has known and accepted for a thousand years. In some such fashion are we pleased at a concert by the traditional presentation of a familiar work. It confirms our notion of how the thing should be done and our approbation of the performance and of ourselves proceeds in hand-in-hand amicability by a broad and easy road.

Aside from a very few heaven-scaling achievements in concerto literature such as Beethoven's E-flat, Schumann's, and Brahms' D-minor, whose performance should be frequent and whose audition should be approached with something of sacramental gravity, aside from these we might do well with quite rare hearings 
of the large majority of constantly programmed concertos. Of course we shall wish, probably for generations to come, to hear sometimes one or two of the Mozart concertos, if given in concerthalls of appropriately intimate size. The Chopin F-minor may not be a time defying work, but its somewhat overdressed loveliness is engaging even now when we have accustomed ourselves to a more stimulating beauty. Dust has settled forever, let us hope, on the Hummels, the Henselts, the Litolffs and Mendelssohns-"die unendlichen nichtssagenden." The Concerto Pathétique of Liszt, originally for two pianos, is forgotten. One of the others will conceivably follow. Rubinstein's inflated scores enjoy longer and longer periods of repose. Some of Saint-Saens' show indubitable signs of dry rot though the fourth and fifth have a right to be heard more frequently and deserve long and happy lives for their ingratiating charm, suavity and sometimes cynically dextrous handling of gossamer material.

The plaster has already fallen from the poor skeleton of Massenet's one essay in this field; the Martucci is no more; those by Dupont and Godard were still-born and the one by Theo. Ysaye must have seen the light but a short time. The Grieg is still fresh. Many of the Russian concertos are lit by dramatic moments all too quickly obscured by thick German writing - the later Rachmaninoff excepted, as well as that colorful and gratefully short one movement concerto by Rimsky-Korsakoff. Of Tschaikowsky, why not "the other one" sometimes? It tosses its mane less dramatically and paws the earth in less fiery manner but it is beautiful in quite its own way. The extremely Lisztian concerto in B-flat by Bortkiewicz is brilliant and grateful but unoriginal. Max Reger's one concerto for piano is a rather splendid effort. It is done on a big canvas with surprisingly gorgeous color. The middle movement, a slow one, differs in atmosphere and content from any concerto $I$ know. There is a hint of something legendary, almost operatic, that reaches quite to the remote regions of modern imagination. Then there is a hand-filling, ear-filling concerto in D-flat by Sinding that Shattuck would play well.

It is regrettable that Sibelius has given us no piano concerto. He should do a good one. His long melodic line and individual impressionism-a kind of musical fresco-should make capital concerto material.

Of concertos written by learned but quite uninspired lesser German composers there is a small regiment. From these, by reason of superior taste, emerges one by Otto Singer. The concertos by Xaver Scharwenka fail to intrigue the interest. Quite 
Of Notable Piano Concertos, Neglected and Otherwise 401

unaccountably Moszkowski's concerto failed to take on. It deserves more attention-it is sparkling, witty and often distinguished.

One must feel grateful for a very small number of modern concertos most useful for teaching. I insist that when a concerto is too old fashioned, too trite and threadbare for the public, that the schoolroom is no place for it and I resent the remark: "This should be left for the conservatory student and boarding-school girl." We might well be more careful of what we offer to an unformed taste than we are of what we offer to the public!

Two modern examples, occuring to memory at this moment, are highly useful for the teacher who wishes the benefits of concerto study for the pupil who has not the technical equipment for greater epics; one is by Gabriel Pierne, the other, an almost unknown composition, by Isaac Albeniz.

Pierne's concerto is very fresh and lovely, though it must truthfully be said, of extreme paucity of content; but it is so tuneful and so useful for rhythm and crispness of phrasing and is so grateful to the student that even the most conservative teacher must be thankful for it. Instead of the usual andante the middle movement is a scherzo characterized by genuine Gallic piquancy. The Albeniz is less valuable but can be used for less advanced players. The first movement affords some excellent practice in double notes, octaves, and rapid passages. The second movement, a Reverie and Scherzo is slight; the third, built on transformed themes of the first movement, is good rhythmically. The entire composition is not too long.

Comparatively recently there has been brought to hearing in England a concerto by Delius (I think not yet heard in America), and in this country one by George W. Boyle.

Arne Oldberg's rather Brahmsian but scholarly concerto is one of the most dignified compositions of large calibre that America can lay claim to. There are some very dull ones which are occasionally heard when their composers elect to feature them. The MacDowell concertos have made a place for themselves and are likely to last for a long time, though they show a distressing tendency to wear dull in spots-few concertos do not, for that matter.

Passing in review the number of fine concertos, old and new, we find a considerable number that disengage themselves and stand apart and aloft, but how monotonously similar of content and contour! One tires of even great mountain peaks of unvarying profile.

Contemporary piano concertos lean very heavily on either Liszt or Brahms. Very few can claim an individual silhouette. 
I can think of three which seem to me to be exceptions. These seem to be rooted in the nature of the modern piano and to be of the peculiar genius of that instrument. I am speaking of the great Concerto in $\mathrm{C}$ by Busoni, the Concerto Eroico, Op. 8, by Ottokar Novácek, and the Concerto in C-minor, Op. 77, by Charles Marie Widor.

The first of these is widely known by reputation or by slight acquaintance with the score; the other two, I fancy, are being called to the attention of many readers for the first time. These concertos, widely different in physiognomy, are yet related in that they are distinguished from the rank and file of concerto literature by loftiness of purpose, profundity of content, finished workmanship and deep sincerity. Although they show certain hereditary traits which but acknowledge the debt that every composer owes to his predecessors, they are yet so original in concept and execution that not one of them may be said to bear more than a superficial resemblance, and these of a technical character, to other works. One thing they have strongly in common: each one exhibits the authentic piano idiom, and so stands sharply differentiated from the two great classes of modern concertos, which, as has been said, lean so heavily on Liszt and Brahms. The Brahms pensés musicale is not of the piano, but is abstract or absolute. The Liszt habit of thought, while pianistic in every sense, does not always exploit the unique possibilities of the piano as it is understood in modern times. He foreshadowed in some pages of the Sonata quasi fantasia aprds uno lecture du Dante the elaborate and diffused "repetitional percussion" which Busoni uses so tellingly in his transcription of the Bach Chaconne. The intricate and colorful polyphonic web which may be woven on the piano keyboard waited for larger exploitation on Godowsky and Busoni, with a contribution, not generally recognized, from Max Reger. Of course, as has often been pointed out, no one can write as though Debussy had not lived-and no one does.

These features of the piano: its fluid sonority which can be handled in mass and made to surge like waves of the sea, its peculiarly sculptural play of light and shade which gives us a Rodinesque sense of solidity, volume and profile, its vibrant impressionism which the pedal over concurrent harmonies gives us-an impressionism comparable to the effect of broken color in paintingthese eminently modern developments appear richly and plentifully in these concertos.

The gigantic Busoni score-it runs through one hundred and seventy-eight pages (exclusive of the separately printed cadenza) in 


\section{Of Notable Piano Concertos, Neglected and Otherwise 403}

Egon Petri's two piano version-is probably the longest of all piano concertos. It is in five movements and utilizes a male chorus in the last movement to a text from Oehlenschlaeger's "Aladin." It has had public performances-Egon Petri, a disciple of Busoni, being a noteworthy interpreter.

The German text of the choral section will probably make it impossible of future production in countries where it might otherwise be heard, though I am sure some other language could give us an adequate restatement of the text-Latin perhaps! No one could charge Latin as being the vehicle of any unpleasant hangover from the late war.

Personally, I have never been quite happy in the German text for the last movement. It imparts a localizing flavor that seems out of harmony with the super-geographical atmosphere of the work as a whole.

Busoni's commanding position in the world of art has drawn attention to his work at times when one is constrained to believe that its transcendental character could have won the notice of only the very few. He has the uncompromising artistic conscience of great genius. So colossal a work as this piano concerto must necessarily wait upon proper perspective for adequate judgment, but a consideration of its striking differences must impress one even on superficial examination with the sense of having assisted at the discovery of a giant and solitary monument of human imagination.

The first movement, Prologo \& Introito, begins allegro, dolce e solenne. The deftness with which the swift play of harmonic color is handled proclaims Busoni's Latin blood at once. A lesser composer could not have resisted the temptation to be grandiose.

The piano solo begins with a series of magnificent chordal arches whose thematic exfoliation in the following pages imposes stupendous difficulties upon the executant. The first few pages suggest, not in either matter or manner, but in their cosmic magnificence, the opening pages of Strauss' Also sprach Zarathustra. It is difficult to recall any composer who has given such aid to the interpreter as Busoni has done in these pages by vivid and graphic direction through unusual words. The following words arrest the eye upon cursory survey of the score: lampeggiante, burrasco, slanciato, riroegliandasi, fracasso, assotigliando.

The second movement: Pesso giocaso; the third: Pesso serioso, containing some of the most beautiful pages in the whole score; the fourth movement: Al' Italiana, a tarantella movement which in itself demands the utmost of the pianist. The fifth movement: 
Cantico, beginning with a swinging figure similar to the solo beginning of the first movement leads into the choral section. This is very suave and beautiful writing and proceeds by gravely mounting lines over a piano obbligato to a thrilling climax.

It is not the purpose of this article to analyze a score easily accessible, but to redirect attention to a great artistic gospel which no serious student of music can afford to ignore. Very few will ever play it-very few can, but the pianist can learn much about novel effects which may be carried back to the familiar repertoire; the compaser will be struck by the amazing unity in a work of such dimensions and variety. It is an unforgettable lesson in composition to observe how even the slightest ornament is made to bear its share in the symphonic burden.

The brief notices of Ottokar Novácek in biographical dictionaries yields the scant information that he was born in Hungary in 1866 and died in New York in 1900. He played in the Boston Symphony under Nikisch and in the New York Symphony under Damrosch until weakness of the heart compelled him to give up playing when he devoted himself to composition. Three string quartets, two concert caprices for piano, the first a Preludium, the second a Toccata, both dedicated to Grieg, some compositions for violin and a few songs make up the list of his published compositions with the addition of his remarkable Concerto Eroico which is dedicated to Busoni who later gave it its first public performance. Of the concert caprices for violin, the "Pagininistrich" and the "Perpetuum Mobile" are especially effective. Among the songs, the "Flammentod" approaches greatness.

The Concerto Eroico is in one movement with a number of divisions. In content it is abstruse, technically it is very difficult, requiring in addition to exceptionally strong wrists, great dexterity of finger and the mental capacity to sustain an unusual mood through forty-five pages of clasely woven score. Sombre without being fretful, fateful without being pessimistic, funereal at times without lugubriousness, triumphant without becoming bacchannalian, the conclusion leaves one with a sense of the spiritual greatness that accepts life without entirely vanquishing fate. There is just that acceptance of life, almost defiant, which we feel in so many of Beethoven's greatest works, the Appassionata sonata for example -in fact, the impression Nováček leaves is that of a rather Hungarian Beethoven. There is a tragic grandeur that wears a garb more brilliant and exotically colored than does Beethoven. Reading the concerto from the dramatic and threatening opening in C-minor to its clangorous conclusion in E-flat one receives a 
Of Notable Piano Concertos, Neglected and Otherwise $\mathbf{4 0 5}$

picture which might be most well expressed by the splendid lines that open Edwin Arlington Robinson's "The Man Against the Sky":

\author{
Between me and the sunset, like a dome \\ Against the glory of a world on fire, \\ Now burned a sudden hill, \\ Bleak, round, and high, by flame-lit height made. higher, \\ With nothing on it for the flame to kill \\ Save one who moved and was alone up there \\ To loom before the chaos and the glare \\ As if he were the last god going home \\ Unto his last desire.
}

Most musicians are likely to be surprised at the claim that the great organist at St. Sulpice in Paris, distinguished composer of the now classic organ symphonies, is the creator of a noteworthy piano concerto. Anyone familiar with his first concerto for piano, a work written many years ago and bearing the stamp of bygone pianistic fashions, would be totally unprepared for the work of the master's maturity as set forth in his Op. 77.

Charles Marie Widor has been growing steadily through a long life devoted to musical composition-he was born in 1845 and has been organist at St. Sulpice since 18701 His output has been very large although he works slowly. A survey of his compositions would reveal that he has always been most keenly conscious of the tendencies in musical composition. But Parisians, like a large part of the musical world, have been unable to think of Widor in any other role than that of organist and composer for the organ. The impressive and unequalled performances of Bach have overshadowed the composer of the charming piano pieces such as the delicate, gay and very French Carnaval. The Fantasie, Op. 62, for piano and orchestra, a large work dedicated to Isidor Philipp and the sonata for violin and piano, Op. 79, dedicated to Massenet, are works of extremely modern character. They have a quality that is highly individual-they are scholarly without being in the least dry, and original with a dextrous avoidance of the commonplace that is greater than cleverness. But works of monumental magnitude for the piano are very little to the taste of the Parisian musical public. Widor has traveled less than most French composers and virtuosi and has therefore not made a public for himself outside of France.

The Concerto, Op. 77, is dedicated to Francis Planté but was played for the first time at the Cologne concerts by Philipp. Philipp has played it several times since, occasionally under the 
composer's baton. It has not been publicly played, I think, in America, excepting one obscure performance on two pianos.

Certainly, this concerto could be recommended only for a cultured and musically sophisticated audience. It is very long, it is inordinately difficult to play and its import is not easily grasped, but every pianist should know it as an example of the French school of composition at its distinguished best. For the formation of a pianistic style informed with French clarity and precision, limpidity and grace this concerto is invaluable. The many technical problems are varied and great. Oft-times the phrase under the hand is crabbedly intractable, but the problem solved means an enormous gain in that polish and finish which are so admirable in the playing of the best French pianists.

There is but little "brilliant" work in the first movementlittle brilliancy of the fire-works type, but the entire movement is alive with the restrained brilliancy of a well cut and well set jewel. The means are beautifully subordinated to the end and the entire concerto is a document in proof that French piano composition, like French piano playing,' has remained true to the genius of the instrument. Everywhere in these pages there is published a profound knowledge of the peculiar sonorities of the piano, whether it is in a simple unisono, two octaves apart, but lying in the best sounding registers as at the beginning of the solo part, or whether it is in widely dispersed arpeggio passages in cross rhythms such as occur near the finale-always the piano seems to be at its best and graciously disposed to yield a surprising euphony upon the economical material used.

The slow movement is contemplative to a degree almost Franckian, though there is no suggestion of Flemish mysticism: Widor is always French. The orchestration is ravishing here for the first twenty-five or thirty bars, then the piano part moves in greater animation and finally breaks from the orchestra in a very striking cadenza. The second movement merges into the third without a pause.

One of the most effective passages in the last movement is made up of rapid descending scales played in the lower registers of the piano against strings only in which the divided violas playing a wavering cross rhythm of sextolets seem to drop veil upon veil over the rising and falling piano figures and the later entrance in the wood wind of a sharply rhythmical transformation of a theme from the first movement.

This concerto is much less ready to yield results of the kind designated as "effective" than either of the other two we have had 
Of Notable Piano Concertos, Neglected and Otherwise $\mathbf{4 0 7}$

under consideration. Like many other art-works of a very advanced and sophisticated civilization it presents at times a rather glacial exterior. The pianist learns gradually that he is dealing with a quite different set of values. These are not the shouting colors of the virtuoso school. Making all the demands of a virtuoso technic, it asks a more delicately modulated tone, a greater command of half lights, and more degrees of force between mezzoforte and pianissimo. The pianist is suddenly required to speak a very finished French with his fingers!

The music of Widor is a music very different from the music of Debussy and Ravel. He has little to do with that pastel impressionism which is temperamentally such close kin to Oriental mysticism, nor has he much more to do with that Rabelaisianism which Romain Rolland says is more essentially French. His music, as I see it, is of that finely tempered French spirit which expresses itself with an aristocratic disdain of the commonplace and keeps absolute faith with artistic integrity.

These three concertos represent three widely separated phases of modern musical thought: they differ from the large number of compositions in this form not only in degree but in kind: they make widely different demands upon piano technic and upon musical understanding. The pianist who is familiar with them will find himself surprisingly well prepared, musically and technically, for the future development of his art. 